[Devine, N. (2007). Prison Education in Aotearoa New Zealand: From Justice to Corrections. New Zealand Annual Review of Education, 16, 55-72]

\section{Prison Education in Aotearoa New Zealand: From Justice to Corrections}

\author{
Nesta DEVINE
}

\section{Abstract:}

This article considers the changes in policy discourse relating to education in prisons, in the New Zealand context, in the period between the 1950s and the early 21st century. The earlier belief in education as a means to rehabilitation has been replaced by a narrow focus on programmes specifically intended to change the criminal behaviour for which the prisoner has been sentenced. But even these programmes are hard to get into, and available only to selected prison inmates after they have served two thirds of their sentences. Informal education, including physical education and vocational education, have been severely retrenched, as have all forms of work and activity. In this paper I argue that this situation is a logical outcome of the neoliberal construction of education as a private rather than a social or public good, of the reconceptualisation of the public service as an agency of its principal, the party or parties in power. The depersonalising of the inmates of prisons as "prisoners" serves to justify this situation at the same time as it validates the "freedom" of those who conform to social and legal expectations.

1959

No prisoner expressing the desire for education in any form is denied the opportunity if tuition is a practical proposition. Therefore, prison education takes many forms. There are reading lessons for the illiterate, post-primary tuition in academic and technical subjects, opportunities to do extra-mural university work, many kinds of trade training allied to prison industry, and a wide variety of cultural and recreational activities such as drama, music, debating, hobby work, and indoor and outdoor activities.(Department of Justice, 1959, p. 18)

2005

We received a consistent message from all quarters that available meaningful occupation had diminished severely in recent years. This
56 Nesta Devine

was something that concerned us greatly. Idleness does nothing for rehabilitation. As one staff member put it, prisoners who have spent all day (possibly for years) lying in bed are not going to be released and say "I'm now going to go to work" (Office of the Ombudsmen, 2005 , p. 43)

$\mathrm{O}$

ver the last 20 years the attention of educators has focused more and more intently on the formal provision of education in the institutional setting, and less and less on informal education, the contexts of adult education and the non-school sector. In this article I would like to draw attention to some issues concerning the provision of education in New Zealand prisons.

Prisons first entered my life when I was nine years old, when my father was appointed as teacher at the National Prison Centre at Waikeria. We lived there for seven years. My father started at Waikeria in 1956, and became the first full time prison teacher in 1958 (Department of Justice, 1959, p. 19). In the prisons of 2005 the educational opportunities which he had been instrumental in making available for prison inmates in the 1950s and 1960s have all but disappeared. Not only the formal education, but the informal educational possibilities have largely vanished. I would argue that this should be a matter of some concern for educators in this country, since prisons do produce learning whether we like it or not, and prison inmates, to a large extent, represent the failure of our formal and informal learning institutions.

Prison education, or rather education in prisons, has never been exactly a high priority of government, but nonetheless there is a striking discrepancy between the attitudes conveyed by the reports of the Ministers of Justice in the 1950s, Clayton Cosgrove, H. G. R. Mason and later Ralph Hanan, and that revealed by the Ombudsman's report into the conditions in our prisons in 2005. It is of course possible, and even highly likely, that an Ombudsman of the 1950s would not have painted a rosy picture either, and one would not like to claim that all was ever well or exemplary in relation to education in New Zealand prisons. But there has been a traceable change in attitude, which is reflected in the provision and nature of educational programmes in the prisons. This, I argue, is directly due to the relative philosophical positions of the governments involved. The discrepancy between the positions of Ministers of Justice in the 1950s and those of today is, at least in the written record, much greater than that between the respective 
politicians or political parties. Until very recently, when the economics of extensive prison-building caused a rethink on the part of the Labour party, the two main parties have competed for honours as the most rigorous in relation to sentencing and prison conditions. Almost the sole exception to this kind of posture by spokespersons on crime and punishment in Parliament is Nandor Tanczos of the Green Party.

It is fair to say here that public pressure on political parties to deliver ever harsher sentences and prison regimes has been intense. Despite the relative safety of New Zealand, and the dropping rate of crime, few politicians have felt brave or safe enough electorally to challenge the beliefs of those who are vocally represented by the Sensible Sentencing Trust, advocates of "Zero Tolerance", speakers on talk back radio, writers of letters to the editor, and responses to online news items concerning prison affairs, who seem generally to have accepted claims from the USA that it is cheaper to lock up criminals permanently than to attempt to rehabilitate them. A coherent and articulate example of this stance comes from Peter Jenkins, echoing work by A. M. Piehl and J. J. DiLulio in the USA, in his paper "Lock em up and throw away the key" on the Sensible Sentencing Trust website (Jenkins, n.d.). Minister of Corrections Damien O'Connor's press release of May 1, 2006 (and subsequent speeches, e.g., May 11, 2006; May 14, 2006; May 11, 2007) show the efforts of the Labour party to try to initiate a new conversation on prisons and sentencing, but the pressures are obviously constraining.

The earlier reports of the Department of Justice from the 1950s, while reflecting, almost inevitably, on the increase in crime, take up the position - so deeply understood as to be unspoken - that education will assist in the rehabilitation of prison inmates. The obligation also to implement the will of the courts and legislature by constraining prisoners is taken for granted, but not to the extent that the Ministry of Justice is unwilling to experiment with different forms of prison borstals, "open" prisons, community service - in the interests either of rehabilitation, or of preventing assimilation into the core prison population.

Policy documents from the New Zealand Department of Corrections in the early 21st Century take up the explicit position that their responsibility is to ensure the safety of the public, that it is served best by containment, and that the wellbeing and rehabilitation of prisoners come a very distant second to this primary concern.

In the Purpose and Principles Guiding the Corrections System (Department of Corrections, 2006), rehabilitation comes third on the list, after the implementation of sentences and declaration of humane intentions. Rehabilitation is only to be pursued as it is convenient to the prisons and government. It should be noted in this regard that the Ombudsmen's report $(2005$, pp. $7,8,24,40)$ lists a number of ways, including the lack of work and activities, in which New Zealand prisons do not comply with the United Nations Standard Minimum Rules for the Treatment of Prisoners (UN Office of the High Commissioner for Human Rights).

\section{Impact of Neo-Liberalism}

So what happened on the way? The change did not come under the watch of Mason or Hanan, who continued the general impetus of Cosgrove's policies. Obviously the point of change is likely to be related to the change of government philosophy from a generally benign "welfare state" outlook to the harsher certainties of neo-liberalism in the 1980s. The changes are part of a global set of changes in attitude to crime, criminals, law enforcement and sentencing. As the report Changing Minds points out:

Despite the declining crime rates, the incarceration trend has continued to spiral uncontrollably, fed by tough-on-crime attitudes and the political rhetoric of the War on Drugs. This war, and the media frenzy it fuelled, has contributed to America's disproportionate preoccupation with the fear of random violence and what many believed to be the failure of the criminal justice system to punish criminals. In the name of public safety, state and national leaders have justified the priority to build more and more prisons at the expense of classrooms. They have led voters to believe that their personal safety require sacrifices in virtually every area of public spending, including education, when in fact, education has proven time and again to be the indisputable tool for crime reduction and public safety. (Fine et al, 2001, Preface)

With the United States and other countries, New Zealand has almost closed the door to notions of higher, broader or even vocational education in prisons. The Ombudsmen reported "the lack of occupation is a general and significant problem" (p. 7) and "... low levels of rehabilitative and productive activities" ( p. 8). Overall, they said "the lack of meaningful occupation has transpired to cast a long shadow over the work of the department and it is one that does no credit to the New Zealand corrections system" (p. 8). 
Yet there is little specific reference to prisons or prisoners in either Economic Management (The Treasury, 1984) or Government Management (The Treasury, 1987), the key philosophic drivers of the reforms of the 80s and 90s. Indeed, one might expect that the Report of the Ministerial Committee of Inquiry into Violence (Roper, 1987) which addressed the causative elements of family violence and advocated prison reform, to be the most influential policy paper of the 1980s on judicial and penal proceedings, in relation to the conduct of politicians, judges and government departments. It turned out not to be so (Howard League, 2006). The Treasury, although it did not actually address the subject, was far more powerful than Roper in changing the way people thought and acted.

What there is, in terms of specific reference in the two major Treasury briefings, relates to:

1. The responsibility of government to maintain law and order as core responsibilities even of a diminished neo-liberal government;

2. The possibility that even such responsibilities might be contracted out; and

3. The correlation of Maori ethnicity and imprisonment, which is linked to failures of the public education system to respond to the educational needs of Maori over the period of European history in New Zealand (summarized from The Treasury, Vol. 2, 1987, pp. 215-227).

Wider considerations which might be relevant include:

- The changed perception of what it is to be a person;

- The understanding of "education" as a private good;

- The reconceptualisation of government agencies, through "agency theory" as being obliged to serve the ideology of the party in power rather than "the people" or "the Crown";

- The privatisation of aspects of what was the Department of Justice, together with allocation of specific roles such as policy, incarceration, policing, etc., to increasingly separate groups of people.

Economic Management (The Treasury, 1984) is the paper which set in train the processes by which government revenue-earners were initially semi-privatised, as State Owned Enterprises, and in many cases later sold off, often at extremely low prices, and sometimes with such consequences as to cause the government either to rebuild (state banking, postal services) repurchase (rail tracks), resubsidise (Bank of New Zealand, Air New Zealand, railways) or regulate (energy) at a later date. The principle informing the sale of state businesses was that private enterprise is always more efficient (p. 293), and that government should not be in competition with private enterprise because its greater resource base gives it an unfair advantage. In addition, the government was urged to maintain a "neutral" economic climate, on the grounds that "private decisions ...[are] distorted by forms of government assistance or regulation" (p. 132).

In the absence of any direct reference to the Department of Justice, or its component parts, it seems likely that this department was not particularly in the Treasury's sights in 1984. Some principles were established in its report, however, in relation to other areas of social policy: that education, beyond the elementary level, should be seen as a "private good" and hence as a matter for individual investment; that the demand for education "is substantially derived from the need to acquire labour market skills and, because of this, individuals have clear incentives to invest in education"; and that the government's intervention could only be understood in terms of "equalising opportunities" and to do this, it would be more sensible to price tertiary courses according to cost, and to target assistance to students on the basis of need.

\section{The Role of State Servants}

Perhaps most important is the list of indications Economic Management gives regarding the administration of those areas which remain within the public service. They are to be administered by a Chief Executive Officer (CEO) whose role is as closely akin to a private sector CEO as possible (p. 291), and they are to have only two roles: to give policy advice to the Minister, and to carry out the wishes of the party in power (p. 287). In Government Management these two roles were to be institutionally separated or "contestable"(p. 48). But even as the suggestion stands, in Economic Management there is a problem. Is the public service responsible only to its Minister, and then only in terms of the policy planks it has been delivered? The insistence on "transparency" and highly specific goals and objectives made it difficult for employees of government agencies to act as professionals in the wider sense, but the consequences for them when they fail to do so can be severe. 
For these reasons, the newly established Department of Corrections can be forgiven for sounding a little plaintive in its briefing to the Minister in 2005, for it had done, as it understood it ought to do, exactly what was required of it by the Act of 2004. What it did not understand is the influence of memory and tradition. Not only is a government department expected to act as specified under its legislation, but it is also supposed to make sure that the government is not open to criticism from whatever source. And the usual source for criticism, intellectually, theoretically and in terms of practice, lies in the preceding set of organising thoughts and implementing practices.

In the new context then, the Department of Corrections is not allowed any subtleties in its sense of its own responsibilities or mission. It has to implement a "mission statement" which clearly echoes the preoccupations of the party in power. Not surprisingly, the preoccupation of the governing party is essentially to either gain or avoid losing votes, so the mission statement of the Department of Corrections is geared to where it, its Minister and/or the government feels the votes lie: with the Law'n' Order lobby, variously represented by the Sensible Sentencing Trust, letters to the editor, and so on. Not only has Parliament ensured that minimum sentences are longer, that offences of a type which arouse public ire incur special penalties ("home invasion" for instance), but the whole purpose of the Department of Corrections is to keep the public safe. There is none of the ambivalence evident in the discourse of the ministries of Education, or Work and Income, as they strive to define responsibilities to the subjects of their ministrations as those due to "stakeholders", "customers" or "clients".

\section{Persons in Prison}

The customer - as is technically correct for all government agencies, except where, as in education, power has been "devolved" to others is the Crown. The Crown is now a political grouping. The person in prison has become a means by which service is rendered to the Crown, and is not in fact a person. The word person is historically the same term as parson. A parson was a person, even if he wasn't a member of the local aristocracy, because he could "parse" that is, read. A person, in the older sense of the word, is therefore a being whose rights and opinions are to be respected. The change in the nature of incarcerated bodies as persons is apparent in the Corrections Act, which insists that they be known not as "inmates of prisons", the earlier usage, but as "prisoners". Their circumstances become the defining fact of their being.
Let us then examine this question of the nature of persons in these discourses. In the older material, the prisoner is regarded as irresponsible, inconvenient, criminal, but not as inhuman. The welfare of prisoners is discussed seriously, rehabilitation is an earnest intent, education has a place both for the general enhancement of the person and for the acquisition of useful skills which will enable them to gain employment on the "outside". This era perhaps illustrates Foucault's notion of "disciplinarity". Advances in knowledge were applied to the nature of the problem of criminality in various disciplinary forms such as psychology, sociology, or education. Hopes were held that knowledge would aid government to overcome the problems of rising rates of crime, the nature of criminals, and the difficulties of rehabilitation (Foucault, 1977). Since prisoners were human, they were likely to benefit from learning, and some form of teaching was provided, in literacy, school courses through the correspondence school, university courses through Massey University, art sponsored by practising artists, debating, vocational learning such as engine maintenance, farm practice, horticulture, cooking, and building. Many of the practical skills taught to prison inmates revolved around the needs of the institutions themselves - growing food, farming the considerable acreage attached to the prisons, building houses for wardens, maintaining prison vehicles. Sometimes trade with the outside world was involved - as with mail bags, and farm produce.

With its very narrow, mechanistic view of persons as rational choosers, and knowledge as a commodity for sale rather than use, the Treasury documents neatly put aside this sort of view of the possibilities of knowledge and personhood aside. Education is only valued in so far as it can get the student a job; the choice-making individual does not need education in itself and certainly does not need education if he or she is unwilling or unlikely to get a job. The choices of the individual, including the choice whether to be law abiding or criminal (and one suspects, sane or insane) are not susceptible to education, social forces or psychological conditioning: they are rational, self-interested, and manipulable. The role of the state in relation to those who make the wrong choices becomes one of manipulating them to make the right choices. Hence the logic of longer and harsher sentences. Hence also the appeal of behaviourist forms of management.

It is no accident that the principles of applied behaviour modification are acceptable in a neo-liberal form of prison management. Mueller, as president of the Public Choice society, pointed out the 
synchronicity between the self-interested figure used by economists "Homo economicus" - and the behaviourist model of the human being as governed by reward as reinforcer (Mueller, 1986)

Deleuze refers to this form of governmentality as "societies of control" as distinct from the earlier forms identified by Foucault as "societies of disciplinarity" (Deleuze, 1990). His point does appear to be a good one, insofar as present practice defies almost all the relevant disciplines and appropriate forms of knowledge. The discourse which is in use is not that of criminology, sociology or psychology, but is rather a very circumscribed set of notions about the individual drawn from economics and applied behavioural analysis. In this discourse, the prisoner is a highly rational choice-maker, whose bad choices are wilful rather than structural. Education and knowledge are understood as forms of wealth, and ethical decision-making in the field of justice takes on forms of cost-benefit analysis which are acceptable to current notions of public accounting or accountability.

The consequences for the provision of education are profound. Now that education is a private good, to be freely chosen by the autonomous individual, it is no longer available to prisoners, except where it can be shown to result in a public good. Courses are therefore available in drug and alcohol reform, in basic literacy, and in Straight Thinking (Department of Corrections, n.d.). However, in order that the public should not be deprived of the benefit of these public goods, and apparently in the belief that knowledge deteriorates unless used, these courses are not generally available until a prisoner has served two thirds of his or her sentence (Office of the Ombudsmen, p. 50). This policy, the 66 percent rule, suggests a rather naïve belief that prisoners are not in a position to be making decisions about drugs and alcohol, despite substantial evidence to the contrary. The problematic nature of this position is illustrated by the case of a young woman who was before the court for crimes of violence committed while in prison. The judge ordered that she take part in a drugs/violence course, but said that although normally this would not be available until she had served two thirds of her (indefinite, i.e., very long) sentence, she should be allowed to do it immediately, in the interests of the staff who found her, in her present state, unmanageable ("Woman's violent history...", 2006). It seems interesting to note that "education" is to be made available to this offender not in her interest, but in the interests of the (limited) society with which she must still engage.

\section{Educational Issues}

To sum up this part of the argument then, the reformed, neo-liberal form of administration allows accountability only to the employer, that is, the governing party of the day, and by requiring transparent accountability only in such terms, removes the possibility, unless explicitly stated, that the service should exert any form of responsibility, moral or otherwise, to other parties. Since education is a private good, it is not a responsibility of government to provide this to anyone beyond the stage of elementary education in reading and mathematics. Formal education beyond literacy and numeracy is therefore no part of the responsibilities of the Department of Corrections, unless it can be assumed to have an immediate and direct impact on offending.

Since the government requires of the Department of Corrections that it should keep the public "safe", it does offer programmes which have this specific aim. There are programmes for paedophiles, courses for drug and alcohol abusers, and a course aimed at general deviancy. The primary object here is not the benefit of the inmate. Increasingly, however, the country's prison inmates are not people with problems of the traditional kinds. More and more people are being imprisoned for crimes relating to property, traffic offences, failures to pay fines, and, it was announced recently, failures to appear in court (Grunwell, 2006). Such expansion of the range of offences for which imprisonment is ordered is having its effect on the size of prison musters, and on the nature of the person who is typically imprisoned.

However, since people who serve less than 12 months do not usually get access to any form of rehabilitative programme (Office of Ombudsmen, 2005, p. 45), it might be expected that imprisonment for minor offences will not increase the amount of education or rehabilitation offered, although prison as a school for crime will continue to function as usual. Indeed, there is some evidence that the size of the prison muster, and consequent shifting of prisoners without notice, is interfering with the delivery even of those programmes which are available.

Since many of the inhabitants of our prisons are people who find it difficult to get and keep jobs, it might be considered that engagement in productive work would be a good way of both reducing the considerable costs of maintaining prisons, and of teaching usable skills. To this end large-scale farming, horticulture, building, engineering workshops have been established in the past, as can be seen in this Report from 1959: 
Trade training has been maintained and extended wherever possible. New motor mechanics workshops with built-in educational facilities have been provided this year at Invercargill Borstal and at Wi Tako Prison; another at National Prison Centre is being planned. Carpentry instruction featured at Invercargill and National Prison Centre is systematic and benefits a substantial number of inmates.

Less systematised but still useful carpentry, joinery, and cabinetmaking training is afforded at Auckland and Wi Tako. Courses in welding and drainlaying are carried out at Invercargill and National Prison Centre. Good training in printing is given at $\mathrm{Mt}$ Crawford Prison. A tailoring class is held at New Plymouth. Instruction in dairying, sheep farming, pig raising and poultry farming is afforded mainly at Invercargill, National Prison Centre, Wi Tako, Pa parua, and New Plymouth; hairdressing, market gardening, and dressmaking classes are the features of the work at Arohata.

Every effort is being made to increase the educational opportunity in every prison industry. Facilities for group tuition, technical literature, and help from correspondence tuition are means to this end.

A wide variety of activities such as hobby work, cultural group activity, e.g., drama, debating, music, and indoor and outdoor games, plays its part in affording healthy occupations. The greatest difficulty to be overcome is the lack of proper facilities. In all the planning for new buildings provision is being made for classrooms, hobby rooms, and libraries. (Department of Justice, 1959. p. 20)

However, under the model of dividing agencies according to their purpose, the business side of prisons was devolved to an agency called CIE (Corrections Inmate Employment). This new subsection of the Department of Corrections was charged with finding work for prison inmates. However, this work had to be self-sustaining, that is to say, it had to make a profit. Given that prison inmates have to be supervised at all times, and the cost of supervision has to come out of the expenses of the business, any work undertaken by prisoners has a built-in cost disadvantage to overcome before it can be regarded as profitable. When it can demonstrate a profit, it runs the risk of incurring the wrath of business (and economists) because, since the wages are low, it is inimical to the market as a form of subsidised government economic activity. Moreover, the prevailing enthusiasm for contracting out government work has led to the decision that forms of labour which serve the prisons themselves - the gardens at Waikeria for instance - can be more "efficiently" provided by private enterprise, so that even existing work has been closed down. Consequently very little work is available to prison inmates, and the opportunities for learning a trade or useful skills have been diminished.

\section{Existing Forms of Education in Prison}

There are forms of education in prison - indeed education as a process of learning is unavoidable in any social circumstance. Much of what prisoners learn, they learn from each other. Prisons are hotbeds of bullying and intimidation, and prisoners learn to accept, avoid or manage such behaviour in a multitude of ways, not all of them desirable.

The Corrections Act, 2004 lays down the obligations of the Department in relation to the provision of education:

\section{- 78 Information and education needs of prisoners}

- (1) A prisoner is entitled-

- (a) to reasonable access to news;

- (b) so far as is practicable, to access to library services;

- (c) to access to further education that, in the opinion of the prison manager, will assist in-

- (i) his or her rehabilitation; or

- (ii) a reduction in his or her reoffending; or

- (iii) his or her reintegration into the community.

- (2) The Crown is not required to provide a prisoner with any of the education referred to in subsection $(1)(c)$ free of charge unless-

- (a) there is an entitlement to receive that education free of charge (whether under the Education Act 1989 or under another enactment); or

- (b) the education is-

- (i) provided to a prisoner with poor literacy skills; and

- (ii) designed to improve those skills. (Corrections Act, 2004, section 78)

The Department of Corrections provides its own interpretation of the Act in the Purposes and Principles of the Corrections Act 2004 (Department of Corrections, 2006). Two paragraphs are devoted to victims and restorative justice. The paragraph with educational potential says: 
Offenders must, where appropriate and so far as is reasonable and practicable in the circumstances, be provided with access to any process designed to promote restorative justice between offenders and victims. (p. 3)

Likewise, families are supposed to be involved, "so far as is reasonable and practicable" in:

planning for participation by the offender in programmes, services and activities in the course of his or her sentence. (p. 3)

Since only prisoners on long sentences are offered participation in any programmes, activities, or services - except for church services, the possibility for most families of taking part in such decision making is minimal. Moreover, the Department of Corrections does not, in practice, show much enthusiasm for the presence or influence of families at all. It can be difficult to make contact, or even to know in which prison a prisoner is being held.

The third relevant section in the Purpose and Principles... is:

Offenders must, so far as is reasonable and practicable in the circumstances within the resources available, be given access to activities that may contribute to their rehabilitation and reintegration into the community. (p. 3)

The possibilities for education in this paragraph are circumscribed first by the very instrumental association of some programmes with "rehabilitation and reintegration", and second by the qualifiers regarding circumstances and resourcing. To address the issue of what kinds of education are regarded as contributing to rehabilitation and reintegration, the Corrections service makes available a limited number of drug and alcohol programmes, (to which only those who are drug and alcohol free can be admitted(!)), and the course "Straight Thinking" (Department of Corrections, n.d.), which is designed to put offenders on the right track (but only available to those serving sentences longer than 12 months). To address a more specific need, there is a Cognitive Behaviour Therapy course available for sex offenders.

Most interesting in this sense is the growth in Maori cultural programmes. The resurrection of Maori cultural education within this environment has been the work of a few dedicated Maori officials within the Department of Corrections. Their achievement has been tremendous. It calls into high relief the absence of cultural education opportunities for those who do not identify as Maori - and perpetuates the myth that Europeans are not culturally located. Unfortunately
Pacific Islanders and others are expected to share this cultural desert, as being not-Maori. There are some "faith-based" programmes, which might be held to cover all that is necessary from European cultures.

\section{Alternatives}

Are there alternatives? Yes. At the very least, we could conform to the UN requirements for minimal levels of work and activity. There is research which suggests that prisoner participation in post-compulsory education has a positive effect on recidivism.

The data presented here suggest that our present national policy of not providing higher education to men and women in prison is costly and dangerous. The decision to not educate produces negative consequences for women and men in prison, persons who work in prisons, the children of inmates and our communities. In addition, the evidence presented here demonstrates that a national policy which supports higher education for men and women in prison is cost effective, creates safer communities and prisons, and transforms the lives of prisoners, their children and, in all likelihood, the generation after that. Funding college-in-prison programs does not take money away from individual citizens, nor does it weaken any one person's chance of receiving federal support for college. (Fine et al., 2001)

The originators of the Cognitive Behaviour Therapy programme for sex and drug offenders now regard it as inadequate and would like to supplement it with a wider form of understanding aimed at getting the offender to become a more whole person, not just an avoider of temptation.

Prof. Tony Ward, (Dept. Psychology, Victoria University) ... was involved in setting up the sex offender treatment programme at Rolleston Prison (Kia Marama). Since 1998, along with other international writers, he has published several papers setting out the case for broadening the scope of CBT programmes beyond the "one size fits all" model.... Ward argues that the current focus on risk factors and relapse avoidance is a necessary but insufficient treatment aim. What is needed is a broader focus by CBT programmes to encompass the positive human goods or goals all humans seek in order tolive satisfying and good lives. He calls these "primary human goods". (Howard League, 2006, p. 1) 
In Britain there is a programme supported and implemented by The Shannon Trust, which aims to use prisoners who can read to assist illiterate prisoners to learn to read (Shannon Trust, 2006). In Ireland, there is a suggestion that the educational programmes which were used in the times when much of their prison population was political rather than criminal could be used to advantage for a non-political population (Irwin, 2003). From several sources there are suggestions that a liberal arts programme has had a positive effect on recidivism (Steurer \& Smith, 2003; Coughlin \& Clark, 1991)

\section{Altering Circumstances Or Altering Ideas?}

In New Zealand, the Howard League points out that the pressure on prisons and police cells is likely to bring about the revival of community-based sentences, not for educational or rehabilitative reasons, but for pragmatic fiscal reasons. Contracting out custodial work, already curtailed by the present government, has been brought into public question by the murder of a seventeen year old who was being transferred from jail to a court hearing (Gower, 2006). These are instances of the practical consequences of neoliberal policies, and can be altered without altering the fundamental philosophic position. This seems to me to be a specific arena in which the neoliberal construction of persons needs most urgently to be challenged. The inmates of our prisons are doing some very important work in the articulation of neo-liberalism. They exemplify the unfree - and one has to remind oneself that liberalism is at least at a certain level about freedom. Freedom is a meaningful concept only if its antithesis is also meaningful. The imprisoned are necessary, to identify the free, just as the unemployed are necessary to valorize the employed. And the lower the benchmark for freedom, the more important it is to imprison those who do not comply with the requirements. Perhaps that is the real educational role of prisons.

However, even within the understanding that Government and the Department of Corrections seem to have of their own role, they could be playing it better. Denis O'Reilly sums it up:

Take education. $20 \%$ of prisoners are assessed as being illiterate. Last year the prison education budget was under-spent by $44 \%$ and this year it will be under-spent by $33 \%$. Obviously someone isn't learning.

\section{References}

Deleuze, G. (1990). Society of control. L'autre journal, Nr. I, Mai 1990.

Deleuze, G. (1992). Postscript on the Societies of Control, from October, Vol. 59, Winter, 3-7.

Department of Corrections. (2005). Post-election briefing.

Department of Corrections. (2006). Purpose and principles guiding the corrections system. Retrieved July 26 from <www.corrections.govt.nz/ public/news/statutory-reports/statmentofintent $>$

Department of Corrections (Research Unit). (n.d.). "Straight thinking". Ch. 6 of The effectiveness of correctional treatment. Retrieved May 22, 2007, from <www.corrections.govt.nz/public/research/ effectiveness-treatment $>$

Department of Justice. (1959). Report of the Department of Justice, AJHR.

Fine, M., Torre, M. E., Boudin, K., Bowen, I., Clark, J., Hylton, D., Martinez, M., "Missy", Roberts R. A., Smart, P., Upegui. D. (2001). Changing minds: The impact of college in a maximum security prison. Collaborative Research by The Graduate Center of the City University of New York \& Women in Prison at the Bedford Hills Correctional Facility, NY. New York State Dept of Correctional Services. Retrieved on June 4, 2007, from

<www.changingminds.ws/05_conclusions/03_policyissues.html >

Foucault, M. (1977) Discipline and punish. (Allen Sheridan Trans.). London: Tavistock Publications.

Gower, Patrick. (2006, November 3). Death in a prison van: Murderer high-risk criminal who could "go off". New Zealand Herald.

Grunwell, R. (2006, October 22). Missed your court date? Expect jail. People on driving charges locked up. Auckland Sunday Star-Times. p. A6.

Howard League. (2006, February). Roper revisited. Newsletter 38, p. 1

Irwin, Tracy. (2003). Prison education in Northern Ireland: Learning from our paramilitary past. The Howard Journal of Criminal Justice, $42(5), 471-484$.

Jenkins, P. (n.d.). "Lock 'em up and throw away the key ..." Sensible Sentencing Trust website <www.safe-nz.org.nz/Articles/lock.htm >

Mueller, Dennis. (1986). Presidential address to the Public Choice Society. Baltimore, March 22. In Public Choice, 51, 2-23. 
O'Connor, Hon. Damien. (2006). Straight thinking is not enough - it's time to think laterally. Press release, May 14, 2006, Department of Corrections.

Office of the Ombudsmen. (2005). Ombudsmen's investigation of the Department of Corrections in relation to the detention and treatment of prisoners. Presented to the House of Representatives in accordance with section 29 of the Ombudsmen Act 1978. Retrieved November 13,2006 , from

$<$ www.ombudsmen.govt.nz/download\%20Misc/Ombudsmen $\% 20$ Report\%20Corrections\%20Own\%20Motion\%202005.pdf >

O'Reilly, Dennis. Nga Kupu Aroha, words of love. Retrieved December 4, 2006, from <www.nzedge.com/features/ar-denis10.html >

Roper, C. (1987). Report of the Ministerial Committee of Inquiry into Violence. Wellington: Government Printer.

Shannon Trust. (2005, July). The Shannon Trust Newsletter. $<$ www.shannontrust.com $>$

Steurer, S. J., \& Smith, L. G. (2003). Education reduces crime: Three-state recidivism study. Executive summary. Management and Training Corporation Institute.

$<$ www.ceanational.org/documents/EdReducesCrime.pdf >

The Treasury. (1984). Economic management: Brief to the incoming government. Parts $1 \mathcal{E}$ 2. Wellington: Government Printer.

The Treasury. (1987). Government management: Brief to the incoming government, Vols 1 \& 2. Wellington: Government Printer.

Thomas A. Coughlin iii, \& Clark, C. H. (1991).Assistant commissioner analysis of return rates of the inmate college program participants. New York: State Of New York Department Of Correctional Services, Division of Program Planning, Research and Evaluation

UN Office of the High Commissioner for Human Rights. "Standard minimum rules for the treatment of prisoners" approved by the UN Economic and Social Council 1957 and 1977.

<www.unchr.ch/html/menu3/6h_comp34.htm >

Woman's violent history earns her indefinite jail. (2006, February 25). New Zealand Herald.

<www.nzherald.co.nz/index.cfm?objectid $=10369989>$

\section{The author}

Nesta Devine is a Senior Lecturer in education at the University of Waikato. She taught for many years in secondary schools, before returning to study in the mid 1990s. Her PhD from the University of Auckland was published as "Public Choice and Education; A critical account of the invisible hand in education", by Praeger in 2004. Since then she has written various papers on philosophy of education, and education policy. Nesta is currently the vice president of the Philosophy of Education Society of Australasia, and urges all readers of this review to attend its annual conference, "Creativity, Enterprise and Policy-New Directions in Education", December 6-9, at the Museum of New Zealand Te Papa Tongarewa, Wellington. Website <www.pesa.org.au $>$. 